\title{
Fish biomarkers from a different perspective: evidence of adaptive strategy of Abramis brama (L.) to chemical stress
}

\author{
Dina Tenji, Bojana Micic, Sandor Sipos, Branko Miljanovic, Ivana Teodorovic and Sonja Kaisarevic*
}

\begin{abstract}
Background: A prerequisite for long-term survival of populations under multi-stress conditions is their capacity to set up efficient adaptive strategies. However, changes in the activity of molecular biomarkers have been for decades considered as early signals of the deterioration of the fish health and evidence of stress-related adverse biological effects. The aim of this study was to show that such changes actually represent adaptive response of fish to chemical stress. Gene expression and enzyme activity level in liver and brain of specimens from two populations of Abramis brama from contrasted habitats (nature reserve and urban) were examined. Selected parameters included biomarkers of general stress, antioxidative defence, xenobiotic metabolism, endocrine disruption, glucose homeostasis, iron homeostasis, and neurotoxicity.

Results: Exposure of A. brama population from urban area to chemical stress was confirmed by assessment of chronic toxic pressure at fish habitats using Toxic Unit approach. The most pronounced response to chemical stress is observed through the activation of antioxidative defence mechanisms in brain and liver at gene and enzyme activity level, high biotransformation capacity of liver, and activation of mechanisms that will meet energy demands and compensate for the metabolic costs of the response to toxicants (higher expression of genes related to glucose homeostasis in the exposed population). Higher hepatosomatic index in the exposed population implies liver hypertrophy due to increased functional load caused by pollution. Body condition factors indicate good overall condition of both fish populations and confirm high efficacy of mobilized adaptation mechanisms in the exposed population.

Conclusions: The study provided the first data on basal expression of a number of genes in A. brama, potentially valuable for biomonitoring studies in absence of clear pollution gradient and/or reference sites (conditions). The study highlights importance of newly identified roles of various genes and proteins, typically considered as biomarkers of effects, and shows that changes in these parameters do not necessarily indicate the deterioration of the fish health. Such changes should be considered as adaptive response to chemical stress, rather than direct proof of ecological impact of pollution in situ.
\end{abstract}

Keywords: Acetylcholinesterase, Adaptation, Antioxidative defence, Biomarkers, Biotransformation, Chronic toxic pressure, Common bream, Gene expression

${ }^{*}$ Correspondence: sonja.kaisarevic@dbe.uns.ac.rs

Department of Biology and Ecology, Faculty of Sciences, University

of Novi Sad, Trg Dositeja Obradovica 2, Novi Sad 21000, Serbia

\section{Background}

In a constantly changing environment, under conditions of ever-increasing anthropogenic pressure, one of the greatest challenges aquatic wildlife faces is coping with chemical pollution. Surface waters contain tens to hundreds of thousands of chemicals including plant protection products, biocides, pharmaceuticals, surfactants, 
personal care products and many more together with numerous transformation products [1]. What is more, chemical pollution is often coupled with hydromorphological alterations and/or other stressors such as eutrophication, oxygen loss, $\mathrm{pH}$ and temperature variation, resulting in complex environmental change requiring simultaneous activation of multiple biochemical and physiological control mechanisms in aquatic animals in order to survive.

The main intake routes of chemicals in fish are the gills, skin and the gut (via the food ingestion). In case of absorption through gills and skin, chemicals go directly into the bloodstream and to the most of the organs, while ingested chemicals first undergo initial intestinal metabolism, absorption and hepatic biotransformation [2]. Once they enter the organism, chemicals or their biotransformation products induce plethora of responses on various levels of organization in almost all organ systems, often resulting in mild to severe adverse effects. However, selection pressures associated with exposure to chemicals have led to the evolution of tolerance, with the most important physiological adaptive mechanisms related to the metabolism and excretion of the target chemical, enhancements in antioxidant responses, and alterations of the life cycle of fish [3]. Depending on the ability of species to cope with the chronic chemical stress, the overall responses might range from gradual population decline (sometimes resulting in species extinction) to the development of biochemical and physiological adaptations as mechanisms for successful maintenance of homeostasis in the polluted environment [3-6].

Phenotypic and physiological changes that develop as adaptations to toxic pressure have a confirmed or inferred genetic basis [7], but so far the processes are well understood in a handful of species for a few chemicals only [3]. Most of the studies on dynamics of gene expression are focused on organisms under controlled laboratory conditions, while data on expression variations in organisms under natural conditions are scarce [8]. Typically, laboratory species are aquarium or farm-reared fish, chosen for practical reasons (e.g., short generation time, small size, easy maintenance in aquaria), but their lower level of genetic diversity in comparison to wild populations can alter responses to anthropogenic chemicals [4]. Moreover, most of the existing studies focus on the effect of one specific stress factor in isolation, while aquatic organisms are typically exposed to multi-stress [9].

In environmental studies, physiological responses in wild fish on the level of gene expression and enzyme activity have been traditionally used as biomarkers of exposure and effects [10], tools supposed to provide information on subtle effects that inevitably precede organism/population level changes and announce or anticipate the typically adverse outcome of exposure to mixtures of toxicants in real-life conditions. In concert with a predictive mixture risk modeling, effect-based methods and field-derived species inventories, in situ tests, among which biomarkers in wild or caged fish have a prominent role, have been recommended as one of the four lines of evidence for assessing the ecological impact of chemical pollution on aquatic ecosystems, to bridge the gap and establish causal links between typically disconnected chemical and ecological assessments $[11,12]$.

In the aquatic environment, a number of pollutants tend to accumulate in sediment and/or biomagnify in food chains, making benthivorous and piscivorous species among the most exposed to their effects. One of such species is a freshwater cyprinid fish Abramis brama (L. 1758; common bream), a bottom dwelling, typical benthivorous fish, feeding on macrozoobenthos including oligochaetes, chironomid larvae, and bivalves [13]. Still, A. brama is considered as LC (Least Concern) species according to IUCN classification. It is autochthonous and widely distributed in Europe and abundantly represented in various freshwater fish communities [14, 15]. Stocks in a number of water bodies are stable. For example, during Joint Danube Survey 2 (JDS2) in 2007, it was the eighth [16], while 6 years later, it was the seventh most abundant of all identified fish species and also the second most abundant rheophilic B species collected during Joint Danube Survey 3 (JDS3) in 2013 [17]. Although there are a few examples of negative reactions of some populations to the anthropogenic pressures $[5,15]$, abundance and fitness of common bream in various watercourses indicate to their good adaptability and tolerance towards changeable temperature and trophic conditions as well as hydromorphological alterations $[14,15]$.

However, data on specific biochemical and physiological adaptive strategies of $A$. brama exposed to various anthropogenic stressors including chemical pollution are scarce, especially on a level of early responses other than antioxidative defence. Therefore, we compared gene expression and enzyme activity level in liver and brain from two populations of wild fish, exposed to contrasted environmental conditions at two sites in the Serbian section of the Danube River. We examined responses related to general stress, antioxidative defence, xenobiotic metabolism, endocrine disruption, glucose homeostasis, iron homeostasis, and neurotoxicity. Selected parameters were so far typically considered as biomarkers of effect in environmental studies, but here we discuss their role from a different angle as we hypothesize that the differences in responses of two populations represent adaptive mechanisms of wild fish population exposed to chronic toxic stress. 


\section{Methods}

\section{Abramis brama populations}

Specimens from wild A. brama populations exposed to contrasted environmental conditions at two sites in the Danube River in Serbia were studied. Reference population, living in the conditions of low overall anthropogenic pressure and particularly low chemical stress, is represented by fish caught at the Special Nature Reserve "Gornje Podunavlje (Upper Danube)", a wetland area of nearly 20,000 ha along the left bank of the River Danube between 1367 and 1433 river $\mathrm{km}$. Apart from being protected by national regulations and categorized as IUCN (International Union for Nature Conservation) category IV-Habitat and Species Management Area, it is also designated as a Ramsar site, Important Bird Area (IBA), Important Plant Area (IPA) and Emerald site. Exposed population, living in the conditions of high anthropogenic pressure and consequent high chemical stress, is represented by fish caught downstream of the city of Novi Sad (1250 to 1252 river km). In this, urban area, the Danube River receives untreated municipal wastewaters of the entire city of approximately 300,000 inhabitants, as well as partly treated effluents from oil refinery and a number of diverse industrial facilities. Less than 10 river $\mathrm{km}$ downstream of City of Novi Sad, there is a 6000 ha big Special Nature Reserve "Kovilj-Petrovaradin Marches". Similarly to Gornje Podunavlje, it is designated as a Ramsar site, IUCN category IV Area, IBA, IPA and Emerald site. The reserve is a suitable refuge for a number of rheophilic B fish species, including phytolithophilic A. brama, and provides adequate spawning habitat for the exposed population from our study.

\section{Assessment of chronic toxic pressure at sampling sites using Toxic Unit (TU) approach}

The chronic toxic pressure at sampling sites of interest for the study was evaluated using the Toxic Unit (TU) approach, assuming that concentration addition is a suitable concept for the mixture toxicity assessment [18]. Environmental concentrations of the substances used for TU calculations were taken over from the official report of the Serbian Environmental Protection Agency (SEPA) on surface and groundwater official monthly monitoring of priority substances in 2017 and 2018 [19, 20]. Also, toxic pressure was calculated from the data provided by detailed chemical analyses of water samples taken in the frame of Joint Danube Survey 3 (JDS3) and published by Liška et al. [21], as well as data from large volume sampling (LVSPE) of Danube water in the area of Novi Sad by König et al. [22]. Concentrations of measured substances are given in Additional file 1: Tables S1-S4.

The Chronic Toxic Units (TUch) were calculated for each quantified chemical by dividing its measured environmental concentration (conc $\left.\mathrm{c}_{\mathrm{i}}\right)$ with average chronic No Observed Effect Concentration $\left(\mathrm{NOEC}_{\mathrm{i}}\right.$ ) for fish, daphnia and algae (back-calculated from the database of Posthuma et al. [23] and given in Additional file 1: Tables S1-S4). The overall chronic toxic pressure is calculated as arithmetic sum of chronic TUs and expressed as SUM TUch and also as chronic pressure from organic compounds SUM TUch org.

$$
\text { SUM TUch }=\sum_{n}^{i} \frac{\text { conc }_{i}}{\operatorname{NOEC}_{i}}
$$

\section{Fish sampling and tissue harvesting}

Specimens of $A$. brama were caught during the spawning period, in May 2018, by fishing nets (fishing approved by Provincial Secretariat for Urban Planning and Environmental Protection, Province of Vojvodina, Republic of Serbia, license no. 140-501-1316/2017-04). This study did not involve any experimental manipulation of fish. Fish were killed by a blow to the head and measured for standard length $(\mathrm{cm})$, total length $(\mathrm{cm})$ and weight $(\mathrm{g})$. Fish were dissected, and their gender and maturity was determined by inspection of gonads. For all calculations, both sexes were combined.

From each fish, whole liver and brain were removed and weighted. One half of the tissue was immediately put on dry ice, and upon return to the laboratory transferred to $-80^{\circ} \mathrm{C}$, where samples were kept until further analyses (homogenization, determination of protein levels and enzyme activity). Another half of the tissue was put in RNAlater (Sigma-Aldrich), and then transferred to $-20{ }^{\circ} \mathrm{C}$ until further processing (RNA isolation). Scales for age determination of fish were taken from the first row above the lateral line and below the insertion of the dorsal fin of the left side of the body. They were observed under the dissecting microscope and age was determined by counting annuli on the scale surface. This examination revealed they aged from $3+$ to $6+$ years.

\section{Determination of somatic indices}

Body condition factor (BCF) of fish was calculated according to formula:

$$
\mathrm{BCF}=\frac{\text { whole body weight }(\mathrm{g})}{\text { total length }^{3}(\mathrm{~cm})} \times 100
$$

Hepatosomatic index (HSI) was calculated according to formula:

$$
\mathrm{HSI}=\frac{\text { liver weight }(\mathrm{g})}{\text { whole body weight }(\mathrm{g})} \times 100
$$




\section{Enzyme activity assays}

Brain and liver tissues were homogenized in ice-cold sodium phosphate buffer $(0.1 \mathrm{M}, \mathrm{pH} 7.2)$ in 1:5 ratio $(w / v)$. Homogenization was done on Disruptor Genie homogenizer (Scientific industries, USA), 2 min for liver samples and $1 \mathrm{~min}$ for brain samples, in $1.5 \mathrm{ml}$ Eppendorf tubes with 5 stainless steel bead beaters $(1.5 \mathrm{~mm}$ dia.) and $\sim 10$ glass bead beaters $(0.5 \mathrm{~mm}$ dia. $)$, previously UV sterilized and autoclaved (beads manufactured by Biospec products, USA). Homogenates were centrifuged at $9000 \times g, 20 \mathrm{~min}, 4{ }^{\circ} \mathrm{C}$. Supernatants were collected, divided into aliquots, and used for enzyme activity measurements as enzyme source. In all enzyme assays, enzyme activity was determined photometrically using Multiskan ${ }^{\mathrm{TM}}$ GO microplate spectrophotometer (Thermo Scientific). Protein concentration in each sample was determined using Pierce BCA Protein Assay Kit (ThermoFisher Scientific), in triplicates, following the manufacturer's instructions, also using Multiskan ${ }^{\mathrm{TM}}$ GO microplate spectrophotometer (Thermo Scientific). Obtained values were used for the expression of enzyme activities per $\mathrm{mg}$ of proteins.

Catalase (CAT) activity was measured by the method described by Claiborne [24], and as modified by Velki et al. [25]. In our study, the procedure was adapted for measurement in 96-well plates. In each well, the reaction mixture contained: $120 \mu \mathrm{l}$ (for liver samples) or $100 \mu \mathrm{l}$ (for brain samples) of sodium phosphate buffer $(0.1 \mathrm{M}, \mathrm{pH} 7.2)$, $125 \mu \mathrm{l}$ of $0.04 \mathrm{M}$ hydrogen peroxide (Sigma-Aldrich), and the reaction was initiated by adding $5 \mu \mathrm{l}$ of liver samples or $25 \mu \mathrm{l}$ of brain samples. The decrease in absorbance due to hydrogen peroxide decomposition was measured in triplicates at $240 \mathrm{~nm}$, for $3 \mathrm{~min}$, in $7(30 \mathrm{~s})$ steps, at $25^{\circ} \mathrm{C}$. The CAT activity was expressed as $\mu \mathrm{mol}$ of hydrogen peroxide decomposed per $1 \mathrm{~min} / \mathrm{mg}$ of proteins. Molar extinction coefficient of $43.6 \mathrm{M}^{-1} \mathrm{~cm}^{-1}$ was used for calculation.

Carboxylesterase (CES) activity was measured by the method described by Hosokawa and Satoh [26], using p-nitrophenyl acetate (pNPA) as a substrate, and as modified and adapted for 96-well plates by Velki et al. [25]. In each well, the reaction mixture contained: $15 \mu \mathrm{l}$ of $1 \mathrm{M}$ Tris-HCl buffer (pH 8.0; Sigma-Aldrich), $200 \mu \mathrm{l}$ of $1 \mathrm{mM}$ pNPA (Sigma-Aldrich) dissolved in acetonitrile and $15 \mu \mathrm{l}$ of sample in GET solution (preparation: $15 \mu \mathrm{l}$ of liver sample in $60 \mu \mathrm{l}$ or $30 \mu \mathrm{l}$ of brain sample in $45 \mu \mathrm{l}$ of GET solution (1:5 w/v 85\% glycerol (Zorka, RS), $0.2 \mathrm{M}$ EDTA (Centrohem, RS), $1 \mathrm{M}$ Tris-HCL in distilled water, $\mathrm{pH}$ 7.4). The increase in absorbance due to formation of $p$-nitrophenol (pNP) was measured in triplicates, at $405 \mathrm{~nm}$, for $2 \mathrm{~min}$, in $5(30 \mathrm{~s})$ steps, at $25^{\circ} \mathrm{C}$. The CES activity was expressed as $\mu \mathrm{mol}$ of pNP formed per minute per mg of protein. Molar extinction coefficient of $16,400 \mathrm{~m}^{-1} \mathrm{~cm}^{-1}$ was used for calculations.
Glutathione S-transferase (GST) activity was measured by the method described by Habig and Jakoby [27], using 1-chloro-2,4-dinitrobenzene (CDNB) as a ultraviolet chromogenic substrate, and adapted for 96 -well plates by Velki et al. [25]. In each well, the reaction mixture contained: $180 \mu \mathrm{l}$ of $1 \mathrm{mM} \mathrm{CDNB}$ (Sigma-Aldrich), $5 \mu \mathrm{l}$ of liver or $10 \mu \mathrm{l}$ of brain sample and $50 \mu \mathrm{l}$ of $25 \mathrm{mM} \mathrm{GSH}$ (Sigma-Aldrich). The increase in absorbance due to production of conjugate (CDNB-SG) in reaction between CDNB and GSH was measured in triplicates, at $340 \mathrm{~nm}$, for $3 \mathrm{~min}$, in $10(20 \mathrm{~s})$ steps, at $25^{\circ} \mathrm{C}$. The GST activity was expressed as $\mu \mathrm{mol}$ of conjugated GSH in $1 \mathrm{~min} / \mathrm{mg}$ of proteins. Molar extinction coefficient of $9600 \mathrm{M}^{-1} \mathrm{~cm}^{-1}$ was used for calculations.

Acetylcholinesterase (AChE) activity was measured by the method described by Ellman et al. [28], using acetylthiocholine iodide as a substrate, and adopted for 96-well plates by Velki et al. [25]. In each well, the reaction mixture contained: $190 \mu \mathrm{l}$ (for liver samples) or $200 \mu \mathrm{l}$ (for brain samples) of sodium phosphate buffer (0.1 M, pH 7.2), $10 \mu \mathrm{l}$ of $1.6 \mathrm{mM}$ DTNB (Sigma-Aldrich), $20 \mu \mathrm{l}$ of liver or $10 \mu \mathrm{l}$ of brain sample, and the reaction was initiated by adding $10 \mu \mathrm{l}$ of $156 \mathrm{mM}$ acetylthiocholine iodide (Sigma-Aldrich). During the reaction, thiocholine (hydrolyzed from acetylthiocholine iodide by AChE) reacts with DTNB resulting in yellow colored product (5-thio-2-nitrobenzoic acid anion). The increase in absorbance was measured in triplicates, at $412 \mathrm{~nm}$, for $5 \mathrm{~min}$, in $20 \mathrm{~s}$ steps, at $25^{\circ} \mathrm{C}$. The AChE activity is expressed as $\mu \mathrm{mol}$ of acetylthiocholine iodide hydrolyzed in $1 \mathrm{~min} / \mathrm{mg}$ of proteins. Molar extinction coefficient of $16,400 \mathrm{M}^{-1} \mathrm{~cm}^{-1}$ was used for calculations.

\section{Quantitative real-time PCR analysis (RQ-PCR)}

Total RNAs from the liver and brain tissue was extracted using the TRIzol reagent (Invitrogen, CA, USA), according to supplier's instructions. The average RNA yield was $1.5 \mu \mathrm{g} / \mu \mathrm{l}$, while the A260/A280 ratio ranged from 1.9 to 2.1 , as determined spectrophotometrically using BioSpec-nano (Shimadzu Corporation, Japan).

Reverse transcription of total RNA from each sample to cDNA was conducted using High Capacity cDNA Reverse Transcription Kit with RNase inhibitor (Applied Biosystems). The reaction mixture was prepared in a $20 \mu \mathrm{l}$ total volume, containing $2 \mu \mathrm{g}$ of RNA, random primers and MultiScribe reverse transcriptase (Applied Biosystems) according to the supplier's instructions. The reverse transcription was conducted in the Veriti Thermal Cycler (Applied Biosystems), under the following conditions: $25^{\circ} \mathrm{C}$ for $10 \mathrm{~min}, 37^{\circ} \mathrm{C}$ for $120 \mathrm{~min}$, and $85^{\circ} \mathrm{C}$ for $5 \mathrm{~min}$.

The RQ-PCR reaction was prepared in a $12.5 \mu \mathrm{l}$ total volume, containing $1 \times$ Power SYBR Green PCR Master Mix reagent (Applied Biosystems, UK), $500 \mathrm{nM}$ of each primer, template $(2.5 \mu \mathrm{l}$ of product from reverse 
transcription reaction, $2.5 \times$ diluted), and DEPC-treated nuclease-free water (Sigma). The RQ-PCR was performed on the Mastercycler ${ }^{\circledR}$ ep realplex (Eppendorf, Germany), under the following cycling conditions: $50{ }^{\circ} \mathrm{C}$ for $2 \mathrm{~min}, 95^{\circ} \mathrm{C}$ for $10 \mathrm{~min}, 40$ cycles of $95^{\circ} \mathrm{C}$ for $15 \mathrm{~s}$, and $60^{\circ} \mathrm{C}$ for $1 \mathrm{~min}$.

The housekeeping gene for $40 \mathrm{~S}$ ribosomal protein s11 (40s11) was used as an endogenous control. Expression of the following genes was tested: heat shock protein $70-h s p 70$, cortisol receptor-cr, extracellular signal-regulated kinase 2-erk2, cytochrome oxidase subunit 1-cox1, extracellular superoxide dismutasesod, glutathione peroxidase $1-g p x 1$, nuclear factor erythroid 2-related factor 2-nrf2a-nrf2a, cytochrome P450 1a-cyp1a, microsomal glutathione s-transferase $3 a-m g s t 3 a$, estrogen receptor $\alpha-e r \alpha$, estrogen receptor $\beta$-er $\beta$, pyruvate carboxylase $-p c$, glycogen phosphorylase liver isoform $-p y g l$, transferrin variant $\mathrm{d}-t f d$, and myelin basic protein-mbp. Primer sequences for tested genes were adopted from the pertinent literature

Table 1 Primer sequences used for the RQ-PCR analysis

\begin{tabular}{|c|c|c|c|}
\hline Gene & Primer sequence $\left(5^{\prime}-3^{\prime}\right)$ & Published in & $\begin{array}{l}\text { Primer } \\
\text { efficiency }\end{array}$ \\
\hline \multicolumn{4}{|c|}{ Endogenous control } \\
\hline $40 s 11$ & $\begin{array}{l}\text { F:CCGTGGGTGACATCGTTACA } \\
\text { R:TCAGGACATTGAACCTCACTGTCT }\end{array}$ & {$[30]^{\mathrm{a}}$} & 2.05 \\
\hline \multicolumn{4}{|c|}{ General stress } \\
\hline hsp70 & $\begin{array}{l}\text { F:GGCAGAAAGTTTGATGACCCA } \\
\text { R:GCAATCTCCTTCATCTTCACC }\end{array}$ & {$[31]^{\mathrm{a}}$} & 2.09 \\
\hline $\cos 1$ & $\begin{array}{l}\text { F:GGAACTTAGCCCACGCA } \\
\text { R: AAGCACGGATCAGACGA }\end{array}$ & {$[31]^{\mathrm{a}}$} & 1.92 \\
\hline erk2 & $\begin{array}{l}\text { F:GTTGAAGACGCAGCACTTGA } \\
\text { R:ACAGGTTTGATGGCTTCAGG }\end{array}$ & {$[32]^{b}$} & 2.00 \\
\hline $\mathrm{Cr}$ & $\begin{array}{l}\text { F:GTGAGACTGCAAGTGTCCAA } \\
\text { R:TCTCTCTTCACTATGGCCT }\end{array}$ & {$[31]^{\mathrm{a}}$} & 1.97 \\
\hline \multicolumn{4}{|c|}{ Antioxidative defence } \\
\hline sod & $\begin{array}{l}\text { F:GAGTTCGACAACACAATCTATGCCAC } \\
\text { R:CAGCCTTGACTGAGGTCTCC }\end{array}$ & {$[33]^{c}$} & 2.01 \\
\hline$g p \times 1$ & $\begin{array}{l}\text { F:AGATGTCATTCCTGCACACG } \\
\text { R:AAGGAGAAGCTTCCTCAGCC }\end{array}$ & {$[34]^{b}$} & 2.07 \\
\hline$n r f 2 a$ & $\begin{array}{l}\text { F:GAGCGGGAGAAATCACACAGAATG } \\
\text { R:CAGGAGCTGCATGCACTCATCG }\end{array}$ & {$[35]^{b}$} & 1.96 \\
\hline \multicolumn{4}{|c|}{ Xenobiotic metabolism } \\
\hline cypla & $\begin{array}{l}\text { F: TTCGGAGCCGGTTTCGACAC } \\
\text { R: CCTCGAGGAGCGGCAGG }\end{array}$ & {$[33]^{c}$} & 1.98 \\
\hline mgst3a & $\begin{array}{l}\text { F:GATATGTGGCGCTAACCGGA } \\
\text { R:ACTGTACATTGTTGGATACGG }\end{array}$ & {$[36]^{b}$} & 2.00 \\
\hline \multicolumn{4}{|c|}{ Endocrine disruption } \\
\hline era & $\begin{array}{l}\text { F:ACTGCCCACAAACTCTCACC } \\
\text { R:TGGGAACTCATAGGCTCCAT }\end{array}$ & {$[30]^{\mathrm{a}}$} & 2.05 \\
\hline $\operatorname{er} \beta$ & $\begin{array}{l}\text { F:CCAGGTCCATTTGTTGGAGT } \\
\text { R:TGAGGTCTGGGGAGAAAATG }\end{array}$ & {$[30]^{\mathrm{a}}$} & 2.04 \\
\hline \multicolumn{4}{|c|}{ Glucose homeostasis } \\
\hline$p c$ & $\begin{array}{l}\text { F: GTAAAGGTGAAGCCAGGCCAG } \\
\text { R:TCCCCTTCCAGGCTGCTGTC }\end{array}$ & {$[33]^{c}$} & 2.01 \\
\hline pygl & $\begin{array}{l}\text { F: TGGCCAATCACAGGATCGTTA } \\
\text { R:TTCTCAATTGCCTCCACGTCA }\end{array}$ & {$[33]^{c}$} & 2.02 \\
\hline \multicolumn{4}{|c|}{ Iron homeostasis } \\
\hline$t f d$ & $\begin{array}{l}\text { F: GGCACACTGGCAAGTTTACAT } \\
\text { R: GGCTTTCAGGTGTCTTGCAG }\end{array}$ & {$[33]^{c}$} & 2.09 \\
\hline \multicolumn{4}{|c|}{ Neurotoxicity } \\
\hline$m b p$ & $\begin{array}{l}\text { F: AATCAGCAGGTTCTTCGGAGGAGA } \\
\text { R: AAGAAATGCACGACAGGGTTGACG }\end{array}$ & {$[37]^{b}$} & 1.91 \\
\hline
\end{tabular}

${ }^{a}$ Cyprinus carpio-, ${ }^{\mathrm{b}}$ Danio rerio- and ${ }^{\mathrm{C}}$ Rutilus rutilus-specific sequences 
(Table 1). For each sample, 2 to 4 independent RQ-PCR reactions were conducted. In each reaction, samples were analyzed in duplicate and endogenous control was included in each plate.

Normalized gene expression (NE) was calculated as previously described [29] according to formula:

$$
\mathrm{NE}=\frac{E_{40 \mathrm{~s} 11} \mathrm{Ct}_{40 \mathrm{~s} 11}}{E_{\text {target }} \mathrm{Ct}_{\text {target }}},
$$

where NE is normalized gene expression; $E_{40 \mathrm{~s} 11}-\mathrm{PCR}$ amplification efficiency of the housekeeping gene; $E_{\text {tar- }}$ get - the PCR amplification efficiency of the target gene; $\mathrm{Ct}_{40 \text { s11 }}$-threshold cycle of the PCR amplification of the housekeeping gene; $\mathrm{Ct}_{\text {target }}$-threshold cycle of the PCR amplification of the target gene. The $\mathrm{Ct}$ is defined as the cycle at which the fluorescence rises appreciably above the background fluorescence.

\section{Statistical analyses}

Raw data were checked for normality using D'Agostino \& Pearson omnibus and Shapiro-Wilk normality test. Further statistical analyses of the results were performed using software GraphPad Prism 6. For comparison of the responses in two fish populations, in cases of normal distribution of the data, parametric unpaired $t$-test was used, otherwise, non-parametric Mann-Whitney $U$ test was used. In all tests, the probability level for statistical significance was set to $p<0.05$.

\section{Results}

Chronic toxic pressure at $A$. brama habitats

According to the results of the official monthly monitoring of priority substances, priority hazardous substances, river basin specific pollutants and selected pesticides in water $([19,20]$, data given in Additional file 1: Tables S1 and S2) during 2017 and 2018 the chronic toxic pressure was higher in protected than in urban area, but the contribution of organic chemicals to the overall toxic pressure is almost negligible (Max SUM TUch org 0.03) along the whole river section of interest for this study (Table 2).

According to the more detailed chemical analyses (Additional file 1: Tables S1-S4) of water samples taken at protected area (Bogojevo) and in the urban area of city of Novi Sad in the frame of JDS3 [21], chronic toxic pressure is up to 2.5 higher in urban area (SUM TUch 0.82 and 1.36 vs. 0.54 ), while chronic toxic pressure deriving from organic compounds (metals omitted) is up to 3 times higher in urban area (SUM TUch org 0.65 and 1.21 vs. 0.41). High SUM TCch org values were also calculated based on LVSPE data [22] in Novi Sad metropolitan area, at untreated municipal wastewaters discharge point (SUM TUch org 0.82) (Table 3).

\section{Somatic indices}

The values of somatic indices, BCF and HSI, are presented in Fig. 1. Individual fish length and weight was proportional in both populations, which resulted in uniformed BCF with small deviations. Hence, although only slightly higher (13\%), an average BCF of exposed

Table 2 Chronic toxic pressure calculated according to official monitoring data [19, 20]

\begin{tabular}{|c|c|c|c|}
\hline & \multicolumn{2}{|l|}{ Protected area } & \multirow{2}{*}{$\begin{array}{l}\text { Urban area } \\
\text { Novi Sad }\end{array}$} \\
\hline & Bezdan & Bogojevo & \\
\hline \multicolumn{4}{|l|}{ SUM TUch } \\
\hline 2017 & $0.4133(0.2372-0.7659)$ & $0.502(0.2882-1.6786)$ & $0.3594(0.2280-0.6007)$ \\
\hline 2018 & $0.9219(0.22502-2.6422)$ & $0.7489(0.0159-2.3934)$ & $0.3646(0.1163-1.0479)$ \\
\hline Spring 2018 & $0.9463(0.5706-1.6044)$ & $0.3178(0.1933-0.4084)$ & $0.4510(0.1865-0.7222)$ \\
\hline \multicolumn{4}{|l|}{ SUM TUch org } \\
\hline 2017 & $0.0015(0-0.0089)$ & $0.0009(0-0.0058)$ & $0.0010(0-0.0045)$ \\
\hline 2018 & $0.0041(0.00005-0.0201)$ & $0.0052(0-0.0363)$ & $0.0022(0-0.0092)$ \\
\hline Spring 2018 & $0.0126(0.0008-0.0201)$ & $0.0027(0.0012-0.0038)$ & $0.0045(0.0021-0.0092)$ \\
\hline \multicolumn{4}{|c|}{ Number of measured organic compounds $>$ LOQ } \\
\hline 2017 & $4(0-6)$ & $3(0-9)$ & $4(0-10)$ \\
\hline 2018 & $6(1-13)$ & $6(0-16)$ & $5(0-8)$ \\
\hline Spring 2018 & $10(5-13)$ & $6(5-7)$ & $6(6-6)$ \\
\hline
\end{tabular}

Values present average of calculations based on $12(2017,2018)$ or 3 (spring 2018 ) measurements, minimum and maximum values measured in respective periods are given in brackets

SUM TUCh the overall chronic toxic pressure calculated as arithmetic sum of chronic TUs, SUM TUch org chronic toxic pressure from organic compounds, LOQ limit of quantitation 
Table 3 Chronic toxic pressure in the River Danube at sampling sites of interest

\begin{tabular}{|c|c|c|c|}
\hline \multirow[t]{2}{*}{ SUM TUch calculated on JDS3 data from Liška et al. [21] } & \multirow{2}{*}{$\begin{array}{l}\text { Protected area } \\
\text { Bogojevo }\end{array}$} & \multicolumn{2}{|l|}{ Urban area } \\
\hline & & Novi Sad 1 & Novi Sad 2 \\
\hline SUMTUch & 0.54 & 1.36 & 0.82 \\
\hline No. of compounds > LOQ used for SUM TUch calculation & 144 & 145 & 141 \\
\hline SUM TUch org & 0.41 & 1.21 & 0.65 \\
\hline No. of organic compounds $>$ LOQ used for SUM TUch org calculation & 136 & 137 & 131 \\
\hline \multirow[t]{2}{*}{ SUM TUch calculated on data from König et al. [22] } & \multicolumn{3}{|l|}{ Urban area } \\
\hline & Upstream Novi Sad & City of Novi Sad & $\begin{array}{l}\text { Downstream } \\
\text { Novi Sad }\end{array}$ \\
\hline SUM TUch org & 0.14 & 0.82 & 0.15 \\
\hline No. of organic compounds > LOQ & 74 & 119 & 87 \\
\hline No. of organic compounds $>$ LOQ used for SUM TUch org calculation & 68 & 100 & 77 \\
\hline
\end{tabular}

SUM TUCh the overall chronic toxic pressure calculated as arithmetic sum of chronic TUs, SUM TUch org chronic toxic pressure from organic compounds, LOQ limit of quantitation

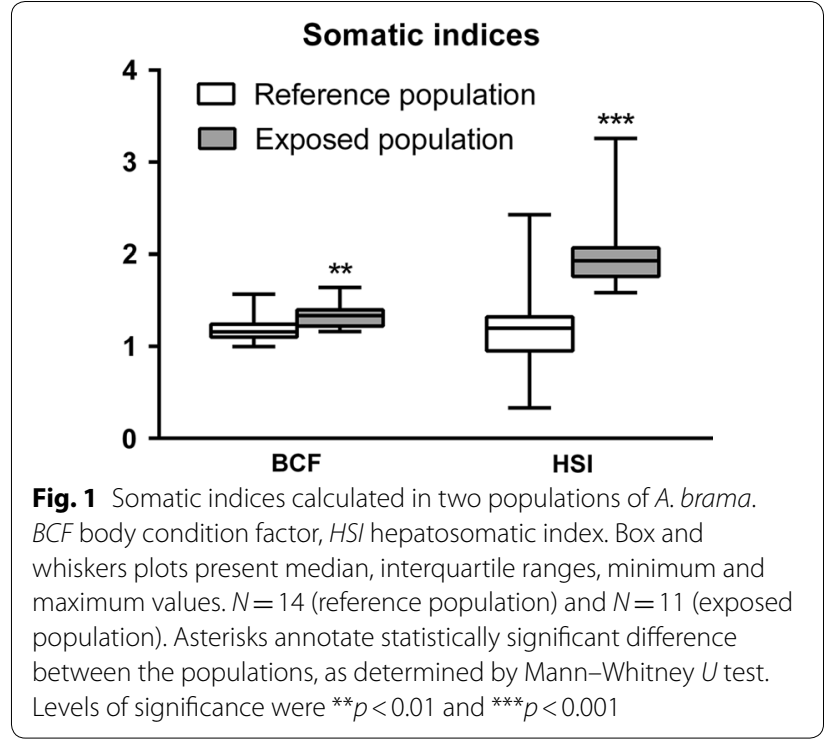

population statistically differs from the average value of the reference population. There was no correlation between fish age and BCF values (correlation coefficients lower than 0.05). Difference in HSI was considerably bigger. In exposed population, average HSI was 1.7 times higher than in reference population.

\section{Enzyme activity}

Results of the enzyme activity assays are presented in Fig. 2. Among the investigated enzymes, antioxidant enzyme CAT exhibits the highest constitutive activity in both examined tissues. The comparison of the average CAT activity in two fish populations revealed that its activity in brain of fish from the exposed population is twice as high as the activity in brain of the fish from the reference population. Although statistically non-significant, considerably higher average CAT activity (31\%) was also observed in liver of the fish from the exposed population. The activities of xenobiotic metabolizing enzymes also differ in two fish populations. The average activity of CES is significantly higher both in liver (85\%) and brain (61\%), and the activity of GST in brain (58\%) of fish from the exposed population. The AChE exhibits the lowest constitutive activity, with higher values in brain, as expected. Slightly, but statistically significant higher average activity was determined in liver, while $36 \%$ lower enzyme activity was measured in brain of fish from the exposed in comparison to the reference population.

\section{Gene expression (RQ-PCR)}

The expression of 15 genes determined by RQ-PCR analysis is presented in Fig. 3. In markers of general stress, considerable differences were observed in levels of gene expression in two fish populations. The expression of hsp 70 was 4.2 times higher and of coxl 4.6 times lower in the exposed population, distinguishing these genes as the most responsive to contrasting environmental conditions. The expression of $\mathrm{cr}$ and erk2 in fish from the exposed population is twice as high as expression in fish from the reference population, although the difference between the groups was not statistically significant. In fish from the exposed population, significant 4.7 times higher expression of $g p x 1,2.4$ higher expression of sod, and 2.7 times lower expression of $n r f 2$ was observed vs. the reference population values. In genes encoding xenobiotic metabolizing enzymes, the trend of lower expression was detected in fish from the exposed population. Similar response was observed in the expression of er $\alpha$, 


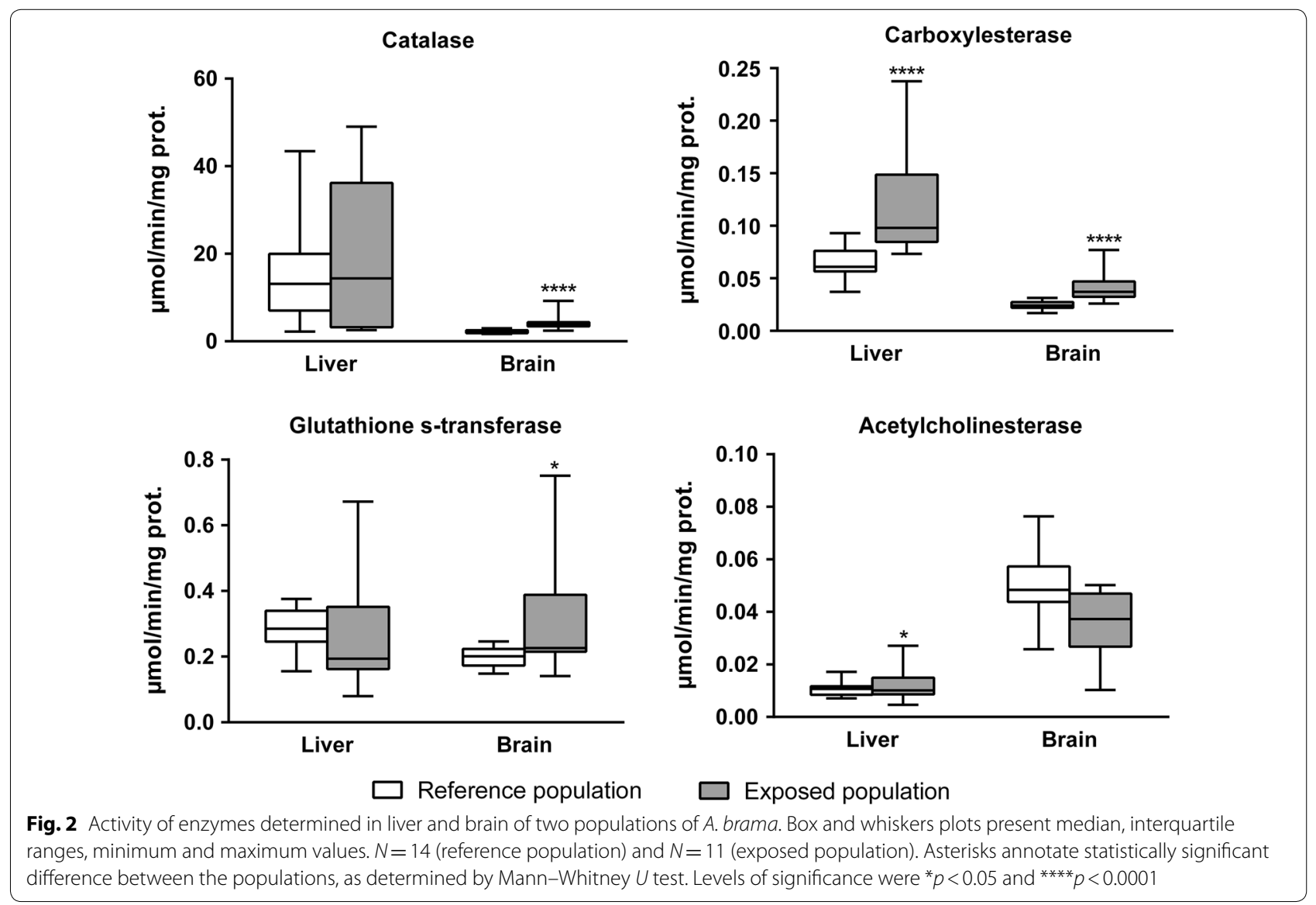

related to endocrine disruption, and for $t f d$, related to maintenance of iron homeostasis (significant 2.2 and 2 times lower expression, respectively).

Expression of genes related to maintenance of glucose homeostasis, $p c$ and $p y g l$, is significantly higher (up to 3.6 times) in fish from the exposed population. The expression of $m b p$, a marker of neurotoxicity, was measured in brain, and no statistical difference was observed between the populations.

Constitutive expression of investigated genes varied, and was the highest in mgst $3 a$, $t f d$, and $m b p$. Low constitutive expression was determined for $c r, \operatorname{cox} 1, \operatorname{er} \beta$, and $p c$, but still enabled differentiation between the two populations.

\section{Discussion}

Confirmation of exposure of $A$. brama population from urban area of the city of Novi Sad to chronic chemical stress

Official monitoring data $[19,20,38]$ indicate that water quality in general supported moderate to good ecological status and did not substantially differ between the three sampling sites. Chemical status of the River Danube at sampling site Novi Sad (urban area) was good, while in the same period, concentrations of some pollutants occasionally surpassed environmental quality standards (EQS) at Bezdan and Bogojevo (protected area). Although sediment content of some pollutants at Novi Sad is somewhat higher than at Bezdan, concentrations do not surpass the sediment target values set by national regulations [39]. According to the official data, the overall chronic toxic pressure to Danube ecosystem can be mainly attributed to metals. Due to a very limited number of potentially toxic organic compounds officially monitored and measured above LOQ, the overall chronic toxic pressure from organic compounds seems misleadingly low and even along the whole river stretch of interest for this study, underestimating the potential impact of non-regulated and non-monitored chemicals and their mixtures $[1,11,22]$.

However, a detailed chemical analysis of water samples taken at Bogojevo and Novi Sad in the frame of JDS3 [21], reveals profound differences in chronic toxic pressure deriving from organic compounds at two sites. Although the number of compounds above LOQ was very close, considerably higher SUM TUch at two sampling sites along the metropolitan area of Novi Sad in comparison to 


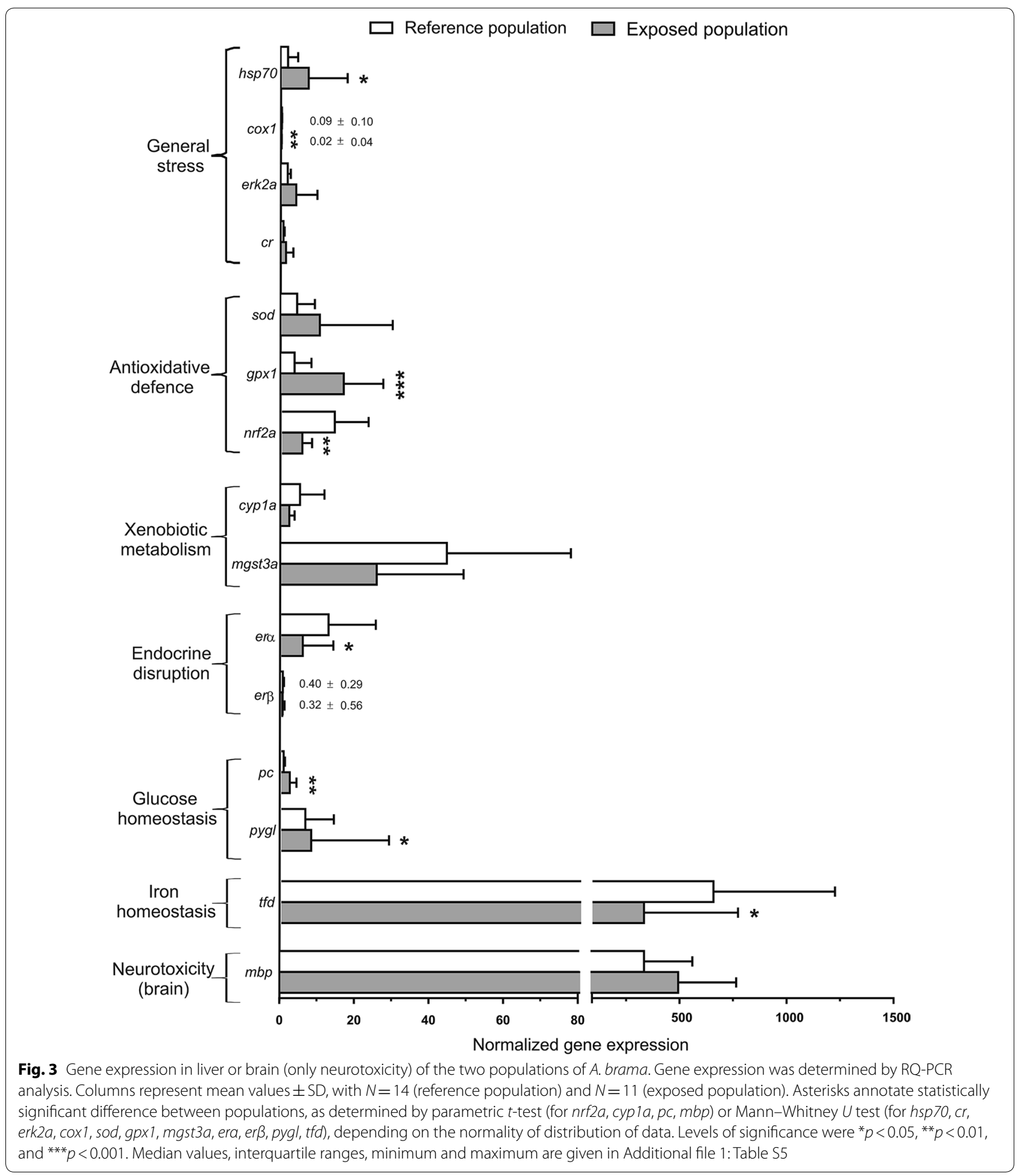

the site at the protected area indicate substantial pressure from untreated waste waters of city of Novi Sad. This was also confirmed by König et al. [22] by LVSPE of the River Danube water upstream Novi Sad. Chemical characterization of the Danube River water in the area of Novi Sad has been conducted also in other studies recognizing this area as a pollution hot spot $[40,41]$.

Studies combining chemical analyses and bioassays on different experimental models underlined the large potential of a high load of chemicals from the group of 
pharmaceuticals, industrial chemicals, pesticides, and personal care products in the Danube River in this area, to activate toxicity pathways and disturb biochemical and physiological homeostasis in various cell lines, zebrafish embryos and fish [22, 42-45]. Still, the questions whether the biological effects observed in vitro can be regarded as an indication of probable ecological impact and weather the impact could be confirmed by adverse effects in resident biota, on individual and population/community level remain open.

\section{The status and condition of $A$. brama populations}

Biometric indices BCF and HSI are reliable indicators of individual fitness and long-term changes of fish health and also, parameters of a high value that mirror the water quality [46]. Decreasing weight of somatic tissue and consequently relatively lower BCF occurs in spring, due to differentiation and growth of reproductive tissue requiring energy reserves during pre-spawning period [47]. BCF values from our study, therefore suggest good nutritional state with well-balanced metabolic expenditures of the fish. The HSI in our study was significantly higher in fish from the exposed population. Two main factors can influence HSI ratio: exposure to the pollutants and fish diet [46]. High HSI in our study probably indicate to liver hypertrophy caused by pollutants, as cell hypertrophy and an increase in liver size to accommodate increased functional load are denoted as adaptive responses to xenobiotic exposure [48]. Liver is also an important storage of energy reserves in non-fatty fish, so low HSI values can be seen in fish on a poor diet [46], which was not the case in our study. Overall, high HSI in fish from the exposed population confirms exposure to chemical pollution, but together with unaffected BCF also indicate good capacity of fish to cope with the stress.

Abramis brama is among the top five most abundant species, making $8.5 \%$ and $6.2 \%$ of the total mass catch in the Danube section along Gornje Podunavlje Reserve and downstream of Novi Sad, respectively [49]. Since it has never been re-stocked, all Danube populations are natural. Overall, the two populations of A. brama are examples of stable populations, living in adequate hydromorphological conditions, with sufficient living and spawning habitats and no diet restrictions.

Chemical contamination of the Danube River section in Novi Sad urban area seems to be a primary stressor that might challenge maintenance of homeostasis on many levels, and eventually jeopardize survival of affected population. Traditionally, biomarkers of effect in resident biota, particularly fish, have been perceived as direct evidence of biological effects in situ [10]. Since our results on individual condition as well as the results of the fish community studies $[16,17,49]$ lead to the conclusion that common bream resists the challenge of chronic toxic pressure, here we shed a light on mechanisms aimed to fight against the chemical stress and consequently challenge the traditional perception of fish biomarker.

\section{Adaptive responses in $A$. brama exposed to chemical stress} Heat shock protein70 (HSP70) and cytochrome oxidase subunit 1 (COX1) are parameters studied for stress identification and as sentinels of exposure to contaminants [31]. HSP70 is constitutively expressed in most cells, upregulated by thermal stress, heat-shock, heavy metals and oxidative stress and with appreciable role in stress tolerance, protein folding, regulation of signal transduction pathways that control cell growth and survival, and suppression of apoptosis [50, 51]. In fish, HSP70/heatshock cognate (HSC)70 may also be used as a source of protein degradation and thus effectively functions as an energy source under stress conditions [50]. High $h s p 70$ expression in A. brama (4.2 times vs. reference population) from the exposed population in our study highlights the importance of adaptive mechanisms related to HSP70 functions. Significant difference was also observed in the expression of $\operatorname{cox} 1$, which regulates oxidative phosphorylation, proton pumping and ATP production in mitochondria. Up-regulation of cox1 was recognized as adaptive response in fish attempting to neutralize the oxidative effect of toxicants [31]. Low cox 1 expression in fish exposed to chemical stress in our study is surprising, and might represent a weak point of the adaptive mechanism of $A$. brama, leading to greater production of mitochondrial reactive oxygen species (ROS). However, it seems that efficient antioxidative defence mechanisms minimize oxidative damage.

Cortisol level in plasma is a well-accepted acute stress indicator, and has been successfully applied to assess a level of stress both in the controlled environments and in the wild (reviewed by Sadoul and Geffroy [52]). Expression of $c r$ in A. brama from the exposed population in our study is not significantly different from the reference population, indicating low level of acute stress in the fish. Absence of acute toxicity of Danube River water downstream of Novi Sad was shown also by fish embryo test (FET) with Danio rerio [53]. Non-significant differences between levels of $\mathrm{cr}$ expression in two populations from our study can indicate adaptive response to chronic stress, due to the hypothalamo-pituitary-interrenal axis desensitization as a consequence of allostatic overload [54]. Interesting observation in fish populations revealed correlation between individual behavioral phenotypes and cortisol levels, distinguishing "bold" 
proactive individuals as low-cortisol responders, masking the common cortisol-related responses to stress [55]. Therefore, it might also be possible that in A. brama from the population facing stress, evolutionary strategy favors proactive behavior and low-cortisol levels (and related $c r$ expression).

Induction of antioxidant defence system and xenobiotic metabolizing enzymes in fish, have been recognized as a golden standard in environmental studies based on biomarker approach for decades [10]. Activation of components of antioxidative defence system observed in $A$. brama from urban area on gene expression (induction of sod and $g p \times 1$ ) and enzyme activity level (induction of CAT) is a proof of strength of their ROS elimination system, and probably one of the most important adaptations to avoid oxidative stress in conditions of chemical contamination. Hepatic antioxidant enzymes activities in $A$. brama exhibit seasonal variations, which can be related to water temperature, oxygen availability, spawning, feeding activities, and fish metabolic activity in general [13]. Up-regulation of Nrf2 is considered as a protective mechanism with an important role in the adaptive response to oxidative stress, widely seen in environmental and toxicity studies. Although expression of $n r f 2 a$ in A. brama from our study was lover in the exposed population in comparison to the reference one, it seems that constitutive levels of Nrf2 are still high enough to induce sufficient antioxidative defence response. This result should also be considered from the aspect of controversial role of Nrf2 in tumor development mainly shown in mammals. On the one hand, Nrf2 is required for protecting the body against cancer while on the other, its overexpression in tumors results in a promotion of tumor growth because it confers a survival and growth advantage to cancer cells $[56,57]$. In our study, balanced expression of $n r f 2$, sufficient to facilitate the induction of antioxidative defence mechanisms, yet low enough to prevent a tumor growth upon exposure to a number of the proven cancerogenic substances detected in the urban area (Additional file 1: Tables S1-S4), might therefore be considered as an adaptive mechanism against carcinogenesis in fish.

Biotransformation enzymes from the CYP1A subfamily are one of the most studied biomarkers of effect of xenobiotics acting through activation of arylhydrocarbon receptor $(\mathrm{AhR})$ as ligand-dependent transcription factor for cyp1a. In vitro study on concentrated water samples of River Danube from Novi Sad site induced significant effect in AhR CAFLUX assay, indicating presence of AhRagonists in the water samples [22, 53]. However, CYP1A enzymes do not seem to play important role in adaptation of A. brama from our study, since the expression of corresponding gene was lower in fish from the exposed population. The protective role of GST in fish is complex.
Apart from a prominent role in phase II of biotransformation of xenobiotics it also serves as an antioxidant by scavenging ROS. Our results indicate that the role of this enzyme in A. brama overall adaptation to chemical stress is not particularly important. Unchanged or decreased activity of biotransformation enzymes (such as CYP1A and GST) in liver is not surprising, since many evidence show that they can also be suppressed or even inhibited in liver of fish exposed to chronic pollution [58-60]. Moreover, seasonal variations of the enzyme activity in liver should also be considered, since it was shown that GST and CAT in different fish species are the highest after the spawning period, which reflects reorganizations in fish metabolism during the reproductive cycle [58]. Seasonal variability in hepatic CYP1A activity (measured as EROD activity), was also shown in A. brama by Yurchenko and Morozov [47], with lower values during the spring in comparison to other seasons. Lack of induction of $m g s t 3 a$ in our study might also result from low expression of $n r f 2 a$, since GSTs are among Nrf2 target genes [61].

Inhibition of CES activity is one of the most widely used biomarker of effect. However, more recent studies reveal that mammalian carboxylesterases have important physiological functions in lipid metabolism and energy homeostasis and probably did not evolve for the sole purpose of metabolizing xenobiotics $[62,63]$. Although there is a lack of evidence of such a dual function of CES in fish, its role in lipid biochemistry is very likely, so high CES activity might be considered as an adaptive mechanism to maintain energy homeostasis in A. brama exposed to chemical stress. It has been found that CES activity varies among fish species, and level of its constitutive activity may play role in lower susceptibility to certain classes of xenobiotics (reviewed by Wheelock et al. [64]). Therefore, significantly higher activity of CES in liver and brain of fish from the exposed population in our study is one more example of adaptive strategy of $A$. brama that might aim for the development of lower sensitivity to xenobiotics due to increased potential for their biotransformation, and maintenance of lipid and energy homeostasis.

Processes of antioxidative defence and biotransformation occur in all organs with different intensity, with liver being distinguished as one of the most active [58]. Apart from liver, brain proved to be an organ with strong antioxidative and biotransformation capacity in A. brama, since the activity of CAT, CES and GST was significantly higher in population exposed to chemical stress. This response can be considered as neuroprotective, and probably contributes to maintenance of functionality of the brain by preventing oxidative stress and harmful effects of chemicals on neurons. Inhibition of AChE 
activity is the best known biomarker of neurotoxicity. Our results reveal that the activity of this enzyme is not jeopardized in brain and liver in the exposed population of A. brama, since no significant enzyme inhibition was shown in any organ. In addition, in both populations similar expression of $m b p$, gene coding the protein essential for formation of myelin in nervous system, was recorded. Knowing that neuroactive (and potentially neurotoxic) compounds largely contribute to chemical pollution of the rivers world-wide [65] including the Danube River in the area of Novi Sad (project FP7 SOLUTIONS, unpublished results), our findings imply to the effectiveness of protective mechanisms in brain of A. brama, aimed to safeguard the transmission of nerve impulses.

Presence of estrogenic contaminants was confirmed at the Novi Sad site by instrumental analyses and related ER-based in vitro screening assays [22, 42, 53]. Our study showed that er $\alpha$ is a higher expressed receptor subtype in A. brama, but surprisingly, its expression in the exposed population was lower in comparison to the reference population. Significant discrepancies that can occur between in vitro screening assays and the induction of estrogenic biomarkers in fish were explained by Yost et al. [66] by the specific involvement of different ER subtypes in the teleost estrogenic response. Moreover, it is possible that potential xenoestrogens are deactivated through biotransformation processes in fish (a process that can't be observed in the in vitro assays), limiting their estrogenic effects, which, together with specific 'cocktail' effects in vivo could provide explanation for such result [67]. Lower expression of er might also result from reallocation of energy resources away from reproduction and towards tolerance mechanism, highlighted in a study of Xie and Klerks [68]. Moreover, the level of er expression highly depends on the stage of reproductive cycle of fish $[66,67]$. Finally, decrease in the expression of genes coding different ER subtypes in fish liver after exposure to synthetic ligands was also reported by other authors [69].

Glucose homeostasis is controlled by liver enzymes including, among others, pyruvate carboxylase (PC) involved in hepatic gluconeogenesis and glycogen phosphorylase which is a key enzyme of glucogenolysis in liver [70]. Expression of genes encoding these enzymes ( $p c$ and $p y g l$, respectively) was higher in fish from A. brama population exposed to chemical stress in our study. Such response indicates great ability of the exposed population to mobilize energy resources and provide sufficient blood glucose levels to compensate for the metabolic cost of defence, the feature which largely determines the tolerance of fish to environmental stressors [9].

Transferrin (TF) is a protein vital to iron metabolism and maintains the iron requirement of cells through its binding and transport of iron [71]. Through transport of iron, TF is responsible for different processes, such as DNA synthesis, oxygen and electron transport, cell proliferation and regulation of the immune system [32, 72]. The TF is known to be synthesized increasingly if body iron stores are low [73], so lower expression of $t f d$ in the exposed population of $A$. brama from our study indicate sufficient levels of iron required for the mentioned processes. TF has also been linked to impaired glucose metabolism, hyperglycemia and insulin resistance [73], so together with $p c$ and $p y g l$ might also be involved in maintenance of glucose homeostasis and prevention of hyperglycemia in the fish exposed to chemical stress.

\section{Implications for water management}

The study implies that differences in gene expression and enzyme activity level in fish from sites with contrasted environmental conditions represent adaptive mechanisms of wild fish population exposed to chronic toxic stress. A number of studies so far (for review see Backhaus et al. [74]) used the differences in responses in wild fish from reference (unpolluted) and exposed (polluted) sites as direct proof of ecological impact of chemical stress. The result of this study proved that adaptive responses of sentinel species should be taken only as one line of evidence of ecological impact of complex chemical pollution [12]. To ensure that consensual conclusions are drawn from a given dataset, decision matrix on how to combine all available lines of evidence has been suggested by Backhaus et al. [74]. Even in cases of high predicted mixture toxicity and clear signal from effectbased (in vitro) assays, our case study confirmed that the responses of sentinel species should be taken as the evidence of chronic toxic pressure which is likely to cause chemically induced ecological impact, but that the final confirmation must come from (repeated) well designed community studies $[12,74]$. In spite of high ecological relevance of using wild fish for the assessment of in situ effects, the choice of species depends on their presence and abundance at all sites of interest, including pollution hot spots. Additional in situ test with caged fish, ideally using the species naturally expected in respective water body type, but absent from the site of interest, would help to distinguish between the ecological impacts of chemi$\mathrm{cal}$ and non-chemical stress, to enable focusing resources on major management tasks.

\section{Conclusions}

The study provides the first data on basal expression of a number of genes in common bream, potentially valuable for biomonitoring studies in absence of clear pollution gradient and/or reference sites (conditions). 
The results of the study reveal that the adaptive strategy of A. brama against chemical stress predominantly relies on highly efficient antioxidative defence system in brain and liver, high biotransformation capacity of liver, and activation of mechanisms that will meet energy demands and compensate for the metabolic costs of the response to toxicants. So far, changes in gene expression and enzyme activity in fish have mostly been analyzed as biomarkers of exposure or effects, with the main purpose to indicate the level and type of contamination in the aquatic environment. Moreover, any changes in the responses of affected vs. reference populations were typically taken as a proof of an undesirable and potentially harmful effects, which would most likely lead to further changes and damages on higher levels of biological organization. However, our study showed that changes in the activity of molecular biomarkers do not necessarily indicate the deterioration of the fish state. Biomarkers should primarily be used as a tool for predicting the state of biota under stochastic environmental conditions [58]. Emerged from contemporary studies, newly identified roles of various genes and proteins, previously considered only as biomarkers of effects, shed new light on a complex network of responses that should, in case of the stable fish populations, be considered as adaptive. We therefore suggest that the observed changes in gene expression and enzyme activity in the present study should be considered as an evidence of exposure to complex mixtures of hazardous chemicals and adaptive response of affected population to chemical pollution, rather than direct proof of ecological impact in situ. Hence, the study supports the concept of evolutionary toxicology, and issues raised by Whitehead et al. [6] describing how the key features of populations, the characteristics of environmental pollution, and the genetic architecture underlying adaptive traits, may interact to shape the likelihood of evolutionary rescue from pollution.

\section{Supplementary information}

Supplementary information accompanies this paper at https://doi. org/10.1186/s12302-020-00316-7.

Additional file 1. Additional tables.

\footnotetext{
Abbreviations

AChE: Acetylcholinesterase; AhR: Arylhydrocarbon receptor; BCF: Body condition factor; CAT: Catalase; CES: Carboxylesterase; cox1: Cytochrome oxidase subunit 1; cr: Cortisol receptor; cyp 1a: Cytochrome P450 1a; era: Estrogen receptor a; erß: Estrogen receptor $\beta$; erk2: Extracellular signal-regulated kinase 2; gpx1: Glutathione peroxidase 1; GST: Glutathione S-transferase; HSI: Hepatosomatic index; hsp70: Heat shock protein 70; JDS: Joint Danube Survey; LOQ: Limit of quantitation; LVSPE: Large volume sampling; mbp: Myelin basic protein; mgst3a: Microsomal glutathione s-transferase 3a; nrf2a: Nuclear factor erythroid 2-related factor 2-nrf2a; PAHs: Polycyclic aromatic hydrocarbons;
}

PCBs: Polychlorinated biphenyls; pc: Pyruvate carboxylase; pygl: Glycogen phosphorylase liver isoform; ROS: Reactive oxygen species; RQ-PCR: Quantitative real-time PCR analysis; SEPA: Serbian Environmental Protection Agency; sod: Extracellular superoxide dismutase; SUM TUch: Arithmetic sum of chronic TUs; SUM TUch org: Arithmetic sum of chronic TUs from organic compounds; TF: Transferrin; tfd: Transferrin variant d; TU: Toxic Unit; TUch: Chronic Toxic Units.

\section{Acknowledgements}

The authors acknowledge financial support of the Ministry of Education, Science and Technological Development of the Republic of Serbia (Grant No. 451-03-68/2020-14/200125).

\section{Authors' contributions}

DT, IT and SK designed the study. DT and BoM have been responsible for the laboratory analyses and calculation of the results. DT prepared the figures, and together with IT and SK designed the concept of manuscript and drafted the manuscript. IT and SK were major contributors in writing the manuscript and its finalization. DT and SS and BrM were involved in the field work, and BrM contributed to specific aspects of the manuscript. All authors read and approved the final manuscript.

\section{Funding}

The study was financially supported by the Ministry of Education, Science and Technological Development of the Republic of Serbia via Grant No. 173037 and the SOLUTIONS project, funded by the EU FP 7 (FP7-ENV-2013-two-stage Collaborative project) under Grant Agreement Number 603437.

\section{Availability of data and materials}

All data generated or analyzed during this study are included in this published article (and its additional file). The datasets used and/or analyzed during the current study are available from the corresponding author on reasonable request.

\section{Ethics approval and consent to participate}

Ethics approval: fishing approved by Provincial Secretariat for Urban Planning and Environmental Protection, Province of Vojvodina, Republic of Serbia, license no. 140-501-1316/2017-04). The study did not involve any experimental manipulation of fish.Consent to participate: not applicable.

\section{Consent for publication}

Not applicable.

\section{Competing interests}

The authors declare that they have no competing interests.

Received: 30 January 2020 Accepted: 2 March 2020

Published online: 18 March 2020

\section{References}

1. BrackW, Aissa SA, Backhaus T, Dulio V, Escher Bl, Faust M, Hilscherova K, Hollender J, Hollert H, Müller C, Munthe J, Posthuma L, Seiler T-B, Slobodnik J, Teodorovic I, Tindall AJ, de Aragăo Umbuzeiro G, Zhang X, Altenburger R (2019) Effect-based methods are key The European Collaborative Project SOLUTIONS recommends integrating effect-based methods for diagnosis and monitoring of water quality. Environ Sci Eur 31:10

2. Pickford KA, Thomas-Jones RE, Wheals B, Tyler CR, Sumpter JP (2003) Route of exposure affects the oestrogenic response of fish to 4-tertnonylphenol. Aquat Toxicol 65:267-279

3. Hamilton PB, Rolshausen G, Uren Webster TM, Tyler CR (2017) Adaptive capabilities and fitness consequences associated with pollution exposure in fish. Philos Trans R Soc B 372:20160042

4. Hamilton PB, Cowx IG, Oleksiak MF, Griffiths AM, Grahn M, Stevens JR, Carvalho GR, Nicol E, Tyler CR (2016) Population-level consequences for wild fish exposed to sublethal concentrations of chemicals-a critical review. Fish Fish 17:545-566 
5. Poulet N, Beaulaton L, Dembski S (2011) Time trends in fish populations in metropolitan France: insights from national monitoring data. J Fish Biol 79:1436-1452

6. Whitehead A, Clark BW, Reid NM, Hahn ME, Nacci D (2017) When evolution is the solution to pollution: key principles, and lessons from rapid repeated adaptation of killifish (Fundulus heteroclitus) populations. Evol Appl 10:762-783

7. Wang Y, Guo B (2019) Adaption to extreme environments: a perspective from fish genomics. Rev Fish Biol Fisheries 29:735-747

8. Rojas-Hernandez N, Véliz D, Vega-Retter C (2019) Selection of suitable reference genes for gene expression analysis in gills and liver of fish under field pollution conditions. Sci Rep 9:3459

9. Petitjean Q, Jean S, Gandar A, Côte J, Laffaille P, Jacquin L (2019) Stress responses in fish: from molecular to evolutionary processes. Sci Total Environ 684:371-380

10. Van der Oost R, Beyer J, Vermeulen NPE (2003) Fish bioaccumulation and biomarkers in environmental risk assessment: a review. Environ Toxicol Pharmacol 13:57-149

11. Altenburger R, Brack W, Burgess RM, Busch W, Escher B, Focks A, Hewitt M, Jacobsen BN, López de Alda M, Ait Aissac S, Backhaus T, Ginebreda A, Hilscherova K, Hollender J, Hollert H, Neale P, Schulze T, Schymanski E, Teodorović I, Tindall AJ, de Aragão Umbuzeiro G, Vrana B, Zonja B, Krauss M (2019) Future water quality monitoring: improving the balance between exposure and toxicity assessments of real-world pollutant mixtures. Environ Sci Eur 31:12

12. Backhaus T, Brack W, Van den Brink P, Deutschmann B, Hollert H, Posthuma L, Segner H, Seiler T-B, Teodorovic I, Focks A (2019) Assessing the ecological impact of chemical pollution on aquatic ecosystems requires the systematic exploration and evaluation of four lines of evidence. Environ Sci Eur 31:98

13. Morozov AA, Chuiko GM, Yurchenko VV (2017) Annual variations in hepatic antioxidant defenses and lipid peroxidation in a temperate fish, common bream Abramis brama (L.). Int Aquat Res 9:249-257

14. Treer T, Opačak T, Aničić I, Safner R, Piria M, Odak T (2003) Growth of bream, Abramis brama, in the Croatian section of the Danube. Czech J Anim Sci 48(6):251-256

15. Shatunovskii MI, Dgebuadze YY, Bobyrev AE, Sokolova EL, Usatîi MA, Crepis OI, Usatîi AM, Cebanu AS (2009) Some regularities of population structure and dynamics variability in bream Abramis brama in water bodies of eastern Europe. J Ichtyol 49(7):503-515

16. Kovac V (2015) Current status of fish communities in the Danube. In: Liska I (ed) The Danube River Basin. The handbook of environmental chemistry, vol 39. Springer, Berlin, pp 359-389

17. Bammer V, György A, Pehlivanov L, Schabuss M, Szaloky Z, Zornig H (2015) Fish. In: The Joint Danube Survey 3. Comprehensive analysis of Danube water quality. ICPDR — International Commission for the Protection of the Danube River

18. Posthuma L, Altenburger R, Backhaus T, Kortenkamp A, Muller C, Focks A, de Zwart D, Brack W (2019) Improved component-based methods for mixture risk assessment are key to characterize complex chemical pollution in surface waters. Environ Sci Eur 31:70

19. SEPA (Serbian Environmental Protection Agency) (2018) Rezultati ispitivanja kvaliteta površinskih i podzemnih voda-2017, Ministarstvo zaštite životne sredine/Agencija za zaštitu životne sredine, Beograd 2018. [Results of operational monitoring of surface and groundwaters 2017]

20. SEPA (Serbian Environmental Protection Agency) (2019) Rezultati ispitivanja kvaliteta površinskih i podzemnih voda-2018, Ministarstvo zaštite životne sredine/Agencija za zaštitu životne sredine, Beograd 2019. [Results of operational monitoring of surface and groundwaters 2018]

21. Liška I, Wagner F, Sengl M, Deutsch K, Slobodník J (2015) Joint Danube Survey 3-a comprehensive analysis of Danube water quality, final scientific report. International Commission for the Protection of the Danube River, Vienna. ISBN 978-3-200-03795-3

22. König M, Escher BI, Neale PA, Krauss M, Hilscherova K, Novak J, Teodorovic I, Schulze T, Seidensticker S, Hashmi MAK, Ahlheim J, Brack W (2017) Impact of untreated wastewater on a major European river evaluated with a combination of in vitro bioassays and chemical analysis. Environ Pollut 220:1220-1230

23. Posthuma L, van Gils J, Zijp MC, van de Meent D, de Zwart D (2019) Species sensitivity distributions for use in environmental protection, assessment, and management of aquatic ecosystems for 12386 chemicals. Environ Toxicol Chem 38(4):905-917

24. Claiborne A (1985) Catalase activity. In: Greenwald RA (ed) CRC handbook of methods in oxygen radical research. CRC Press, Boca Raton, pp 283-284

25. Velki M, Meyer-Alert H, Seiler T-B, Hollert H (2017) Enzymatic activity and gene expression changes in zebrafish embryos and larvae exposed to pesticides diazinon and diuron. Aquat Toxicol 193:187-200

26. Hosokawa M, Satoh T (2002) Measurement of carboxylesterase (CES) activities. Curr Protoc Toxicol 10:4.7.1-4.7.14

27. Habig WH, Jakoby WB (1981) Assays for differentiation of glutathione S-transferases. Methods Enzymol 77:398-405

28. Ellman GL, Courtney KD, Andres V Jr, Featherstone RM (1961) A new and rapid colorimetric determination of acetyl cholinesterase activity. Biochem Pharmacol 7:88-95

29. Muller PY, Janovjak H, Miserez AR, Dobbie Z (2002) Processing of gene expression data generated by quantitative real-time RT-PCR. Biotechniques 32(6):1372-1374, 1376, 1378-1379

30. Szwejser E, Maciuszek M, Casanova-Nakayama A, Segner H, Verburgvan Kemenade BML, Chadzinska M (2017) A role for multiple estrogen receptors in immune regulation of common carp. Dev Comp Immunol 66:61-72

31. Sinha AK, Diricx M, Chan LP, Liew HJ, Kumar V, Blust R, De Boeck G (2012) Expression pattern of potential biomarker genes related to growth, ion regulation and stress in response to ammonia exposure, food deprivation and exercise in common carp (Cyprinus carpio). Aquat Toxicol 122:93-105

32. Shi $X$, Zhou B (2010) The role of Nrf2 and MAPK pathways in PFOS-induced oxidative stress in zebrafish embryos. Toxicol Sci 115(2):391-400

33. Koglin S, Kammann U, Eichbaum K, Reininghaus M, Eisner B, Wiseman S, Hecker M, Buchinger S, Reifferscheid G, Hollert H, Brinkmann M (2016) Toward understanding the impacts of sediment contamination on a native fish species: transcriptional effects, EROD activity, and biliary PAH metabolites. Environ Sci Eur 28:28

34. Malek RL, Sajadi H, Abraham J, Grundy MA, Gerhard GS (2004) The effects of temperature reduction on gene expression and oxidative stress in skeletal muscle from adult zebrafish. Comp Biochem Physiol C Toxicol Pharmacol 138:363-373

35. Timme-Laragy AR, Karchner SI, Franks DG, Jenny MJ, Harbeitner RC, Goldstone JV, McArthur AG, Hahn ME (2012) Nrf2b: novel zebrafish paralog of the oxidant-responsive transcription factor NF-E2-related factor 2 (NRF2). J Biol Chem 287(7):4609-4627

36. Glisic B, Mihaljevic I, Popovic M, Zaja R, Loncar J, Fent K, Kovacevic R, Smital T (2015) Characterization of glutathione-S-transferases in zebrafish (Danio rerio). Aquat Toxicol 158:50-62

37. Wu Q, Yan W, Liu CS, Li L, Yu LQ, Zhao SJ, Li GY (2016) Microcystin-LR exposure induces developmental neurotoxicity in zebrafish embryo. Environ Pollut 213:793-800

38. SEPA (Serbian Environmental Protection Agency) (2019) Sediment quality of rivers and reservoirs in Serbia 2012-2017. Serbian Environmental Protection Agency (SEPA), Belgrade (In Serbian). ISBN 978-86-87159-23-5

39. Official Gazette of Republic of Serbia (2012) Uredba o graničnim vrednostima zagađujućih materija u površinskim i podzemnim vodama i sedimentu i rokovima za njihovo dostizanje ("Sl. glasnik RS. 50/2012). [Regulation on environmental quality standards (EQS) in surface waters, groundwater and sediment]

40. Milić N, Milanović M, Radonić J, Turk Sekulić M, Mandić A, Orčić D, Mišan A, Milovanović I, Grujić Letić N, Vojinović Miloradov M (2018) The occurrence of selected xenobiotics in the Danube river via LC-MS/MS. Environ Sci Pollut Res 25:11074-11083

41. Savic R, Ondrasek G, Blagojevic B, Bubalo Kovacic M, Zemunac R (2018) Spatial distribution and temporal variation of chemical properties of drainage watercourses in rural and peri-urban areas of Novi Sad (Serbia) — a case study. Environ Monit Assess 190:53

42. Hashmi MAK, Escher BI, Krauss M, Teodorovic I, Brack W (2018) Effectdirected analysis (EDA) of Danube River water sample receiving untreated municipal wastewater from Novi Sad, Serbia. Sci Tot Environ 624:1072-1081 
43. Hashmi MAK, Krauss M, Escher BI, Teodorovic I, Brack W (2020) Effectdirected analysis of progestogens and glucocorticoids at trace concentrations in river water. Environ Toxicol Chem 39(1):189-199

44. Hrubik J, Glisic B, Tubic A, Ivancev-Tumbas I, Kovacevic R, Samardzija D, Andric N, Kaisarevic S (2016) Toxicological and chemical investigation of untreated municipal wastewater: fraction- and species-specific toxicity. Ecotoxicol Environ Saf 127:153-162

45. Stanic B, Andric N, Zoric S, Grubor-Lajsic G, Kovacevic R (2006) Assessing pollution in the Danube River near Novi Sad (Serbia) using several biomarkers in sterlet (Acipenser ruthenus L.). Ecotox Environ Saf 65:395-402

46. Teubner D, Paulus M, Veith M, Klein R (2015) Biometric parameters of the bream (Abramis brama) as indicators for long-term changes in fish health and environmental quality - data from the German ESB. Environ Sci Pollut Res 22:1620-1627

47. Yurchenko W, Morozov AA (2019) Intra-annual variability of hepatic ethoxyresorufin-O-deethylase activity in freshwater bream Abramis brama. Biol Rhythm Res 50(5):679-688

48. Williams GM, latropoulos MJ (2002) Alteration of liver cell function and proliferation: differentiation between adaptation and toxicity. Toxicol Pathol 30(1):41-53

49. Miljanovic B (ed) (2016) Program upravljanja delovima ribarskih područja "Srem", "Banat" i “Bačka” (in Serbian). Univerzitet u Novom Sadu, Prirodno/ matematički Fakultet, Departman za biologiju i ekologiju, Novi Sad and JP Vojvodinasume. Petrovaradin. [Fishery management program for "Srem", "Banat" and "Backa" Danube regions. University of Novi Sad, Faculty of Sciences, Department of Biology and Ecology, Novi Sad and JP Vojvodinasume. Petrovaradin]

50. Yamashita M, Yabu T, Ojima N (2010) Stress protein HSP70 in fish. AquaBioScience Monogr 3(4):111-141

51. Padmini E, Tharani J (2014) Heat-shock protein 70 modulates apoptosis signal-regulating kinase 1 in stressed hepatocytes of Mugil cephalus. Fish Physiol Biochem 40:1573-1585

52. Sadoul B, Geffroy B (2019) Measuring cortisol, the major stress hormone in fishes. J Fish Biol 94:540-555

53. Neale PA, Ait-Aissa S, Brack W, Creusot N, Denison MS, Deutschmann B, Hilscherova K, Hollert H, Krauss M, Novaak J, Schulze T, Seiler T-B, Serra $H$, Shao Y, Escher BI (2015) Linking in vitro effects and detected organic micropollutants in surface water using mixture-toxicity modeling. Environ Sci Technol 49:14614-14624

54. Aerts J, Metz JR, Ampe B, Decostere A, Flik G, Saeger SD (2015) Scales tell a story on the stress history of fish. PLoS ONE 10:e0123411. https://doi. org/10.1371/journal.pone.0123411

55. Balasch JC, Tort $L$ (2019) Netting the stress responses in fish. Front Endocrinol 10:62. https://doi.org/10.3389/fendo.2019.00062

56. Ma Q (2013) Role of Nrf2 in oxidative stress and toxicity. Annu Rev Pharmacol Toxicol 53:401-426

57. Robledinos-Antón N, Fernández-Ginés R, Manda G, Cuadrado A (2019) Activators and inhibitors of NRF2: a review of their potential for clinical development. Oxid Med Cell Longev 2019: Article ID 9372182

58. Danilenko SA, Lukyanova ON (2014) Biochemical markers of commercial fish adaptation in estuaries of peter the great bay (the Sea of Japan). J Ichthyol 54(1):85-94

59. Schlenk D, Celander M, Gallagher E, George S, James M, Kullman S, van den Hurk P, Willett K (2008) Biotransformation in fishes. In: Di Giulio RT, Hinton DE (eds) The toxicology of fishes. CRC Press, Taylor and Francis Group, Boca Raton
60. Zhang JF, Shen H, Xu TL, Wang XR, Li WM, Gu YF (2003) Effects of longterm exposure of low-level diesel oil on the antioxidant defense system of fish. Bull Environ Contam Toxicol 71:234-239

61. Klotz L-O, Steinbrenner H (2017) Cellular adaptation to xenobiotics: interplay between xenosensors, reactive oxygen species and FOXO transcription factors. Redox Biol 13:646-654

62. Ross MK, Streit TM, Herring KL (2018) Carboxylesterases: dual roles in lipid and pesticide metabolism. J Pestic Sci 35(3):257-264

63. Lian J, Nelson R, Lehner R (2018) Carboxylesterases in lipid metabolism: from mouse to human. Protein Cell 9(2):178-195

64. Wheelock CE, Phillips BM, Anderson BS, Miller JL, Miller MJ, Hammock BD (2008) Applications of carboxylesterase activity in environmental monitoring and toxicity identification evaluations (TIEs). In: Whitacre DM (ed) Reviews of environmental contamination and toxicology. Springer, Berlin, pp 117-178

65. Busch W, Schmidt S, Kühne R, Schulze T, Krauss M, Altenburger R (2016) Micropollutants in European rivers: a mode of action survey to support the development of effect-based tools for water monitoring. Environ Toxicol Chem 35(8):1887-1899

66. Yost EE, Pow CL, Hawkins MB, Kullman SW (2014) Bridging the gap from screening assays to estrogenic effects in fish: potential roles of multiple estrogen receptor subtypes. Environ Sci Technol 48:5211-5219

67. Nikoleris L, Hansson MC (2015) Unraveling the estrogen receptor (er) genes in Atlantic salmon (Salmo salar) reveals expression differences between the two adult life stages but little impact from polychlorinated biphenyl (PCB) load. Mol Cell Endocrinol 400:10-20

68. Xie L, Klerks PL (2004) Fitness cost of resistance to cadmium in the least killifish (Heterandria formosa). Environ Toxicol Chem 23(6):1499-1503

69. Chandrasekar G, Archer A, Gustafsson J-A, Andersson Lendahl M (2010) Levels of 17b-estradiol receptors expressed in embryonic and adult zebrafish following in vivo treatment of natural or synthetic ligands. PLoS ONE 5(3):e9678. https://doi.org/10.1371/journal.pone.0009678

70. Han H-S, Kang G, Kim JS, Choi BH, Koo S-H (2016) Regulation of glucose metabolism from a liver-centric perspective. Exp Mol Med 48:e218

71. Gomme PT, McCann KB, Bertolini J (2005) Transferrin: structure, function and potential therapeutic actions. Drug Discov Today 10:267-273

72. Sun $Y$, Zhu Z, Wang R, Sun Y, Xu T (2012) Miiuy croaker transferrin gene and evidence for positive selection events reveal different evolutionary patterns. PLoS ONE 7(9):e43936

73. Huth C, Beuerle S, Zierer A, Heier M, Herder C, Kaiser T, Koenig W, Kronenberg F, Oexle K, Rathmann W, Roden M, Schwab S, Seissler J, Stöckl D, Meisinger C, Peters A, Thorand B (2015) Biomarkers of iron metabolism are independently associated with impaired glucose metabolism and type 2 diabetes: the KORA F4 study. Eur J Endocrinol 173:643-653

74. Backhaus T, Segner H, Hollert H, Deutschmann B, van den Brink PJ, Seiler T-B, Teodorovic I, Focks A (2018) Diagnostic toolbox for ecological effects of pollutant mixtures, including bio-tests, trait-based database and detection tool and WoE studies at hot-spot sites. External deliverable of the SOLUTIONS project. https://www.solutions-project.eu/results-products/. Accessed 29 Feb 2020

\section{Publisher's Note}

Springer Nature remains neutral with regard to jurisdictional claims in published maps and institutional affiliations. 